\title{
Laju Produksi dan Karakterisasi Polutan Organik Lindi dari TPA Kaliwlingi, Kabupaten Brebes
}

\section{Production Rate and Organic Pollutant Characterization Leachate from Kaliwlingi Landfill, Brebes Region}

\author{
WAHYU PURWANTA ${ }^{1 *}$ DAN JOKO PRAYITNO SUSANTO ${ }^{1}$ \\ ${ }^{1}$ Pusat Teknologi Lingkungan, Badan Pengkajian dan Penerapan Teknologi \\ Gedung Geostek 820, Kawasan Puspiptek, Serpong, Tangerang Selatan 15314 \\ wahyu.purwanta@bppt.go.id
}

\begin{abstract}
One result of the waste biodegradation process in the landfill is leachate, which is the organic pollutants that are harmful to the environment. Leachate potentially contaminate soil and groundwater. This study aims to determine the leachate quantity and quality of the solid waste in the Kaliwlingi landfill-Brebes through lysimeter test. The quantity of leachate is important to estimate and develope the design specifications of units processing include its treatment methods. While characterization of leachate is important to determine the efficiency of the treatment system or the target pollutant levels to match the desired the leachate quality standard. From the observations obtained that productivity of leachate per waste mass averaged 1,060liters $/ \mathrm{kg}$, while the $\mathrm{pH}$ value of leachate average of 7.6 or tends to alkaline. From the data, the higher the water content the higher productivity its leachate. Characterization of leachate for $B O D_{5}, C O D, N H_{3}-N$ and TKN produce varying values. The average value and the minimum-maximum range obtained; $B O D_{5} 90.7 \mathrm{mg} / \mathrm{l}(65$ $\mathrm{mg} / \mathrm{l}-130 \mathrm{mg} / \mathrm{l}), \mathrm{COD} 9679.7 \mathrm{mg} / \mathrm{l}(6,300 \mathrm{mg} / \mathrm{l}-12,200 \mathrm{mg} / \mathrm{l}), \mathrm{NH}_{3}-\mathrm{N} 134.4 \mathrm{mg} / \mathrm{l}(80 \mathrm{mg} / \mathrm{l}-190 \mathrm{mg} / \mathrm{l})$ and TKN $672.5 \mathrm{mg} / \mathrm{l}(540 \mathrm{mg} / \mathrm{l}-890 \mathrm{mg} / \mathrm{l})$. The $B O D_{5} / C O D$ ratio of 0.01 indicates a low level of biodegradability in organic matter, due to the relatively short observation time and biological degradation process is still ongoing. The value of $B O D_{5} / C O D$ ratio that obtained has not shown representative value to solid waste condition in Kaliwlingi landfill. The results of leachate characterization to some parameters indicate that biomass or waste studied relatively young age and still in the process of decomposition.
\end{abstract}

Keywords:characterization, production, organic, leachate, landfill

\begin{abstract}
ABSTRAK
Salah satu hasil proses biodegradasi sampah di TPA adalah lindi yang merupakan polutan organik yang berbahaya bagi lingkungan karena berpotensi mencemari tanah dan air tanah. Penelitian ini bertujuan untuk mengetahui kuantitas dan kualitas lindi dari sampah di TPA Kaliwlingi Brebes melalui uji lisimeter. Kuantitas lindi penting untuk memperkirakan spesifikasi disain unit pengolahan termasuk metode pengolahannya. Sedangkan karakteristik lindi penting untuk menentukan efisiensi pengolahan atau target kadar polutan yang diinginkan agar sesuai standard baku mutu. Dari pengamatan diperoleh kuantitas lindi per massa sampah rata-rata mencapai 1.060 liter $/ \mathrm{kg}$, sedangkan nilai $\mathrm{pH}$ lindi rata-rata 7,6 atau cenderung alkaline. Dari data pengamatan, semakin tinggi kadar air akan semakin besar kuantitas lindi yang dihasilkan. Karakterisasi lindi terhadap parameter $\mathrm{BOD}_{5}, \mathrm{COD}, \mathrm{NH}_{3}-\mathrm{N}$ dan TKN menghasilkan nilai yang bervariasi. Nilai rata-rata serta rentang minimal-maksimal yang didapat; $\mathrm{BOD}_{5} 90,7 \mathrm{mg} / \mathrm{l}(65 \mathrm{mg} / \mathrm{l}-130 \mathrm{mg} / \mathrm{l}), \mathrm{COD} 9.679,7 \mathrm{mg} / \mathrm{l}(6.300 \mathrm{mg} / \mathrm{l}$ $12.200 \mathrm{mg} / \mathrm{l}), \mathrm{NH}_{3}-\mathrm{N} 134,4 \mathrm{mg} / \mathrm{l}$ (80 mg/l-190 mg/l) dan TKN 672,5 mg/l (540 mg/l-890 mg/l). Rasio $\mathrm{BOD}_{5} / \mathrm{COD}$ sebesar 0,01 menunjukkan tingkat low biodegradability dalam materi organiknya, hal ini disebabkan waktu pengamatan yang relatif singkat dan proses degradasi biologis masih berlangsung.Nilai rasio $\mathrm{BOD}_{5} / \mathrm{COD}$ yang diperoleh belum menunjukkan nilai yang representatif untuk sampah di TPA Kaliwlingi. Hasil dari karakterisasi lindi untuk beberapa parameter menunjukkan bahwa biomassa atau sampah yang diteliti tergolong usia muda dan masih dalam proses dekomposisi.
\end{abstract}

Kata kunci : karakterisasi, produksi, organik, lindi, TPA sampah 


\section{PENDAHULUAN}

Sistem pengelolaan sampah perkotaan selalu memerlukan adanya Tempat Pembuangan Akhir (TPA) baik sebagai tempat pemrosesan akhir dan atau tempat pembuangan akhir sampah. Kesuksesan pengelolaan sampah di hulu baik melalui penerapan Tempat Pengelolaan Sampah Reuse, Reduce, dan Recycle (TPS-3R) atau bank sampah tidak akan menghilangkan keberadaan TPA. Bahkan sebagian besar kota-kota di Indonesia saat ini sangat bergantung pada keberadaan TPA ${ }^{(1)}$. Berdasar Undang-Undang no.18 tahun 2008 suatu TPA harusdikelola dengan prinsip-prinsip ramah lingkungan atau sanitary landfill.

Penerapan sanitary landfill umumnya terkendala dengan pembiayaan yang sangat tinggi, sehingga untuk kota kecil atau kota sedang dapat secara bertahap dengan merubah TPA open dumping menjadi controlled landfill sebelum menuju sanitary landfill. Seperti diketahui bahaya operasional dari TPA open dumping adalah adanya sumber pencemaran dari lindi (leachate) dan emisi gas-gas rumah kaca (GRK) yang dihasilkannya ${ }^{(2)}$. Selain itu TPA yang tidak tertutup juga sumber penyebaran vektor penyakit maupun bau. Secara umum telah diketahui bahwa lindi TPA sering mencemari air tanah dan air permukaan jika tidak diolah terlebih dahulu $^{(3)}$.

Sebenarnya TPA di Indonesia banyak yang sudah dilengkapi unit pengolah lindi tetapi sayang karena pembiayaan yang mahal, maka banyak yang tidak dioperasikan sehingga pencemaran air tanah dan air permukaan terus berlanjut.

TPA Kaliwlingi Kabupaten Brebes dengan luas $4 \mathrm{Ha}$ adalah salah satu TPA yang sejak berdirinya beroperasi dengan open dumping dan akan ditingkatkan sistem operasionalnya menjadi controlled landfill ${ }^{(4)}$. Perbedaan sistem yang baru adalah adanya lapisan pelindung dan penampung lindi berupa geotextile, ventilasi gasbio serta penutupan sampah dengan tanah secara mingguan ${ }^{(2,3)}$. TPA Kaliwlingi menampung sampah dari Kabupaten Brebes sebesar 240 $\mathrm{m}^{3} /$ hari, atau hanya $7 \%$ dari total sampah yang dihasilkan di Kabupaten Brebes yang3.544 $\mathrm{m}^{3} /$ hari. Sampah di Kabupaten Brebes sebagian besar adalah sampah rumah tangga. Adapun sebagian yang lain diangkut ke TPA Kalijurang yang memiliki luas $2 \mathrm{Ha}$.

Secara umum komposisi sampahnya terdiri atas $55 \%$ organik dan $45 \%$ non-organik, dengan curah hujan rata-rata setahun 2.075,07 mm atau rata-rata curah hujan per bulan $173 \mathrm{~mm}$, diperkirakan lindi yang terbentuk akan signifikan untuk diperhitungkan ${ }^{(5)}$. Posisi TPA Kaliwlingi yang hanya berjarak $2 \mathrm{~km}$ dari tepi pantai dengan ketinggian muka air tanah hanya 2 meter akan memiliki tingkat risiko yang tinggi terkait polutan dari TPA terhadapbadan air. Selain itu risiko terjadinya intrusi air laut ke aquifer air tanah di bawah TPA akan menimbulkan problema lingkungan tersendiri.

Peningkatan status TPA dari open dumping menjadi controlled landfill memerlukan pemeriksaan yang seksama seperti kualitas dan kuantitas lindi. Kuantitas lindi penting untuk memperkirakan spesifikasi disain unit pengolahan termasuk metode pengolahannya. Pengukuran kuantitas lindi dapat dilakukan dengan suatu pemodelan atau pendekatan formula (teoritis) berdasar data sampah yang masuk TPA, atau dapat diuji melalui lisimeter (off site). Sedangkan karakteristik lindi penting untuk menentukan efisiensi pengolahan atau target kadar parameter polutan yang diinginkan. Kualitas lindi akan bergantung pada beberapa faktor seperti variasi dan proporsi komponen sampah, curah hujan dan musim, usia timbunan, pola operasional serta waktu dilakukannya sampling ${ }^{(4)}$. Kualitas lindi adalah hasil interaksi dari jenis dan intensitas dekomposisi, kesetimbangan air serta rejim kelembaban ${ }^{(6)}$.

Salah satu kualitas lindi yang paling representatif adalah kandungan materi organik. Besarnya konsentrasi organik (sebagai COD) suatu lindi akan sangat bergantung pada proporsi nutrien, mineral atau organik pada sampah yang ada ${ }^{(7)}$. Pada umumnya lindi mengandung senyawa organik berbahaya seperti golongan aromatik, chlorinated aliphatic, phenols, phthalates, pestisida dan bahkan ammonia $^{(8,9)}$ Oleh karena itu maka untuk mengantisipasi bahaya yang mungkin timbul akibat pencemaran lindi ke air permukaan dan air tanah diperlukan data karakteristik lindi sampah tersebut. Penelitian ini dilakukan untuk mengetahui kuantitas (laju produksi) dan kualitas lindi TPA Kaliwlingi.

\section{BAHAN DAN METODE}

\subsection{Tempat dan Waktu Penelitian}

Penelitian ini dilakukan di dua tempat,yakni di TPA Kaliwlingi guna mengambil sampel sampah pada medio Februari 2014. Sedangkan uji melalui lysimeter serta pemeriksaan lindi dilakukan di laboratorium BTL Serpong antara Maret-Mei 2014.

\subsection{Bahan dan Alat}

Bahan yang digunakan dalam kuantifikasi dan karakterisasi lindi ini adalah sampah yang disimulasikan bersumber dari rumah tangga, pasar tradisional dan komersial serta kotoran sapi 1 liter sebagai starter. Adapun peralatan yang digunakan berupa 4 buah lisimeter (tipikal) tinggi 2 meter dengan diameter $18 \mathrm{~cm}$, alat 
pemotong sampah, timbangan, termometer, $\mathrm{pH}$ meterdan peralatan standar laboratorium untuk pengukuran kadar $\mathrm{BOD}_{5}, \mathrm{COD}$, TKN dan $\mathrm{NH}_{4}-\mathrm{N}$.

\subsection{Parameter yang Diukur}

Kandungan polutan organik dalam lindi sampah dalam penelitian ini direpresentasikan dalam beberapa parameter yang diukur meliputi;

1. $\mathrm{pH}$ (derajat keasaman)

2. $\mathrm{BOD}_{5}$ (Biological Oxygen Demand)

3. COD (Chemical Oxygen Demand)

4. TKN (Total Kjeldahl Nitrogen)

5. $\mathrm{NH}_{4}-\mathrm{N}($ Ammonium $)$

\subsection{Proses Penelitian}

Penelitian di awali dengan pengambilan sampel sampah di TPA Kaliwlingi dengan mengambil sampah dari truk sampah sebanyak 3 jalur asal sampah yakni dari permukiman, pasar tradisional dan pertokoan. Tiap truk sampah memiliki volume $10 \mathrm{~m}^{3}$ ditumpahkan menjadi satu hingga menjadi $30 \mathrm{~m}^{3}$ sampah lalu dicampur dengan pengadukan. Timbulan sampah ini selanjutnya dibagi empat sama rata dengan kode $A 1, A 2, B 1, B 2$ dimana untuk B1 dan B2 dilakukan penyiraman air sebagai simulasi kondisi musim hujan. Penyiraman dilakukan tiga kali sehari selama 48 jam, baru dilakukan pengambilan sampel pada hari ke-3 Sedangkan A1 dan A2 dilakukan pengeringan selama 24 jam sebagai simulasi musim kemarau.Tiap sampel diambil dari sepuluh titik suatu timbulan dan dilakukan pemotongan hingga diperoleh ukuran rata-rata sampah $<400$ mm.Gunamemastikan ukuran sampel sampah selain digunakan alat pemotong juga saringan dengan ukuran $400 \mathrm{~mm}$. Sampel yang sudah seragam ukurannya dimasukkan ke dalam lisimeter dengan tinggi 2 meter diameter $18 \mathrm{~cm}$, sedangkan berat sampah ditimbang sebelum dimasukkan lisimeter. Sisa sampah (> $400 \mathrm{~mm}$ ) yang tidak masuk lisimeter dibuang.

Selanjutnya dilakukan penampungan lindi yang dihasilkan pada hari ke-20, 40, 60, 80 dan 100 untuk dilakukan pengukuran parameter $\mathrm{BOD}_{5}, \mathrm{COD}, \mathrm{TKN}$ dan $\mathrm{NH}_{4}-\mathrm{N}$. Adapun kuantitas lindi diukur secara akumulatif hingga hari ke-100. Lindi dialirkan melalui pipa outlet di dasar lisimeter untuk ditampung di gelas ukur, untuk selanjutnya dianalisis.

\section{HASIL DAN PEMBAHASAN}

\subsection{Kuantitas dan pH Lindi}

Pengukuran jumlah lindi dilakukan dengan menampung dalam gelas ukur yang merupakan hasil akumulatif selama penelitian. Sumber lindi yang utama di alam adalah adanya air hujan serta kandungan air dalam komponen sampah.
Semakin tinggi kadar air semakin tinggi jumlah lindi, sumber lindi selain air hujan juga adanya proses penguraian sampah khususnya sisa makanan, sayuran dan tanaman ${ }^{(11)}$. Hubungan antara kandungan air dalam massa sampah dengan produksi lindi ini juga diamati dalam penelitian ini. Dalam Tabel 1, terlihat bahwa sampel B1 dan B2 yang memiliki kadar air $84,23 \%$ dan $86,60 \%$ memproduksi lindi berturutturut sebesar 19,51 liter dan 22,12 liter dalam 100 hari pengamatan. Hasil lebih rendah didapat pada sampel A1 dan A2 yang tidak disiram air, sebesar 11,78 liter dan 12,11 liter pada periode yang sama. Dari pengamatan juga diperoleh bahwa jumlah lindi selama penelitian relatif terhadap masa sampah adalah berkisar antara 0,775 liter/kg sampah hingga 1,417 liter/kg sampah. Dengan nilai rata-rata kuantitas lindi sebesar 1,060 liter/kg maka sampah dari Kaliwlingi ini termasuk moderat. Kondisi meteorologis yang berbeda di tiap wilayah dapat menentukan perbedaan kuantitas lindi suatu TPA. Dalam banyak penelitian, kuantitas lindi kadang tidak hanya dipengaruhi faktor kandungan air tetapi juga faktor kompaksi dalam operasional sampah di TPA.Semakin tinggi faktor kompaksi akan mengurangi celah antar sampah yang berpotensi meyimpan cadangan air. Hasil selengkapnya dalam studi ini diperlihatkan dalam Tabel 1.

Tabel 1. Kadar air dan kuantitas lindi

\begin{tabular}{cccc}
\hline Sampel & $\begin{array}{c}\text { Kadar } \\
\text { Air }(\%)\end{array}$ & $\begin{array}{c}\text { Volume } \\
\text { lindi (liter) }\end{array}$ & $\begin{array}{c}\text { Produksi lindi } \\
\text { (l/kg sampah) }\end{array}$ \\
\hline A1 & 72,41 & 11,78 & 0,775 \\
A2 & 73,12 & 12,11 & 0,791 \\
B1 & 84,23 & 19,51 & 1,258 \\
B2 & 86,60 & 22,12 & 1,417 \\
\hline
\end{tabular}

Selain itu setiap pengumpulan sampel lindi pada periode penelitian juga dilakukan pengukuran $\mathrm{pH}$ cairan lindi. Nilai $\mathrm{pH}$ merupakan faktor yang sangat penting dalam dekomposisi sampah organik ${ }^{(12)}$. Dari pengamatan diperoleh nilai $\mathrm{pH}$ lindi cenderung alkaline dimana rata-rata 7,66 dengan variasi 6,8 dan 8,2 . Tidak terdapat perbedaan yang signifikan antara sampel kering dan sampel basah. Berdasar pada berbagai penelitian, untuk TPA yang masih berusia muda nilai $\mathrm{pH}$ berkisar 4,5 hingga 7,5. Sedangkan pada TPA tua atau sudah matang/stabil nilai $\mathrm{pH}$ bisa berkisar 6,6 - 7,5 $5^{(3)}$. Gambar 1 memperlihatkan pola nilai $\mathrm{pH}$ sepanjang pengamatan. Menurut Chiandan De Walle (1976), pH lindi menjadi basa di alam sebagai asam lemak volatil bebasdigunakan oleh bakteri untuk menghasilkan $\mathrm{CH}_{4}{ }^{(13)}$. Seperti diketahui penelitian ini juga menghasilkan kondisi anaerobik dimana salah satu produknya adalah gas $\mathrm{CH}_{4}$.Peran $\mathrm{pH}$ sangat penting dalam 
pengolahan lindi, seperti dalam penurunan nilai turbiditas lindi. Penurunan turbiditas akan efektif dengan nilai $\mathrm{pH}$ di bawah 6 sehingga nilai $\mathrm{pH}$ yang alkaline diatur dengan penambahan $\mathrm{H}_{2} \mathrm{SO}_{4}$. Kondisi demikian juga berlaku pada penurunan nilai COD lindi. Sepanjang pengamatan, $\mathrm{pH}$ lindi cenderung menuju sifat alkaline. Menurut Permen LHK no.59 tahun 2016 tentang Baku Mutu Lindi, rentang ambang batas $\mathrm{pH}$ adalah 6 9.

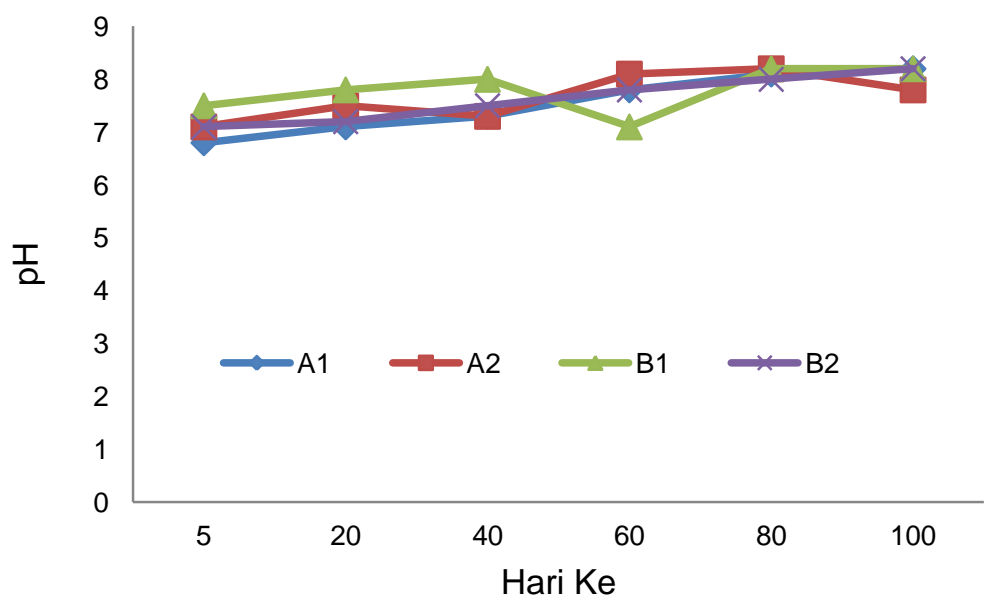

Gambar 1. Nilai pH lindi sepanjang pengamatan

\section{2. $\mathrm{BOD}_{5}$}

$\mathrm{BOD}_{5}$ secara umum digunakan untuk mengetahui tingkat pencemaran organik suatu limbah cair maupun air permukaan. Penentuan nilai $\mathrm{BOD}_{5}$ meliputi pengukuran oksigen terlarut (dissolved oxygen) yang digunakan mikroorganisme dalam oksidasi biokimia pada material organik (limbah) ${ }^{(14)}$. Standar nilai BOD lima hari sangat umum digunakan untuk menggambarkan tingkat polutan organik dalam

limbah cair. Secara teoritis, nilai $\mathrm{BOD}_{5}$ sangat bervariasi bergantung pada usia TPA. Untuk TPA baru atau usia masih di bawah setahun umumnya nilai $\mathrm{BOD}_{5}$ berkisar $2.000-30.000$ $\mathrm{mg} / \mathrm{l}$, sedangkan untuk TPA yang sudah tua (mature landfill) akan berkisar $100-200$ $\mathrm{mg} / \mathrm{I}^{(3,15)}$. Gambar 2 memperlihatkan nilai $\mathrm{BOD}_{5}$ lindi selama periode pengamatan.

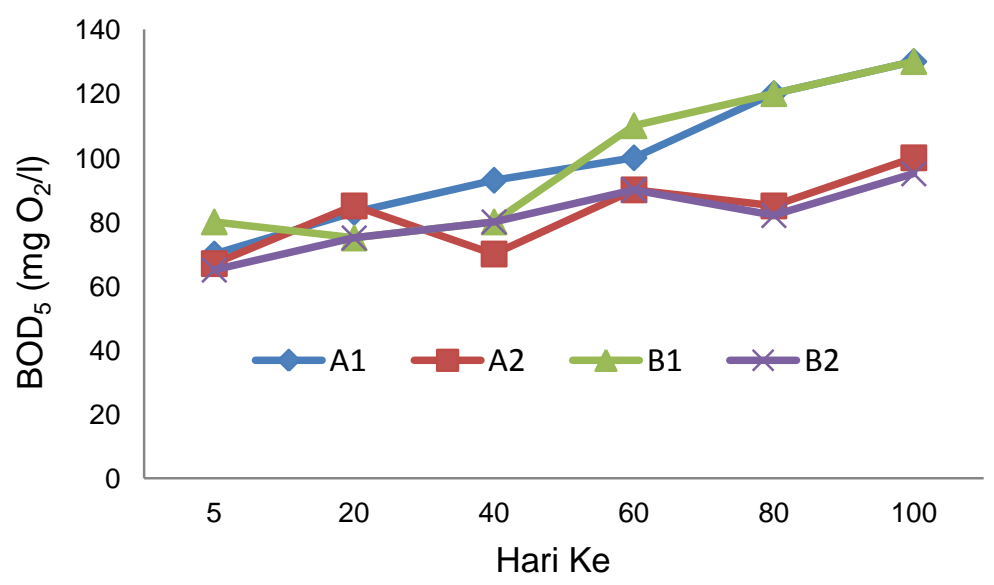

Gambar 2. Nilai $\mathrm{BOD}_{5}$ lindi selama pengamatan

Berdasarkan penelitian ini, didapat nilai $\mathrm{BOD}_{5}$ minimal $65 \mathrm{mg} / \mathrm{l}$ pada sampel $\mathrm{B} 2$ pada pengamatan hari ke-5 serta maksimal $130 \mathrm{mg} / \mathrm{l}$ pada sampel A1 dan B1 pada hari ke-100. Nilai $\mathrm{BOD}_{5}$ yang rendah karena masih sangat singkatnya usia sampah. Dari grafik pada
Gambar2 terlihat adanya kecenderungan nilai $\mathrm{BOD}_{5}$ masih akan meningkat seiring usia sampah atau meningkatnya jumlah sampah organik yang terdekomposisi. Secara umum hasil pengukuran $\mathrm{BOD}_{5}$ dalam penelitian ini untuk usia sampah yang sama, memiliki nilai yang mirip 
dengan hasil penelitian Azis $(2010)^{(10)}$ dan AlWabel $(2011)^{(12)}$. Bervariasinya nilai $\mathrm{BOD}_{5}$ dalam studi ini tidak menunjukkan adanya variasi dalam biodegradasi organik tetapi kemungkinan disebabkan pada teknik pengumpulan lindi sebelum dilakukan uji di laboratorium. Ambang batas dalam baku mutu lindi di Indonesia adalah $150 \mathrm{mg} / \mathrm{l}$.Dari data yang ada jika dianalogikan pada $\mathrm{BOD}_{5}$ dari sumber TPA sampah akan berada pada kisaran $2-5 \%$ dari potensi $\mathrm{BOD}_{5}$ limbah cair perkotaan.

\subsection{COD}

Kebutuhan oksigen kimiawi (COD) adalah ukuran indikasi dari jumlah oksigen yang dapat dikonsumsi oleh reaksi dalam larutan yang diukur, umumnya dinyatakan dalam massa oksigen yang dikonsumsi miligram per liter ( $\mathrm{mg} / \mathrm{l})$. Sebuah tes COD dapat digunakan untuk menghitung kandungan organik dalam larutan. Penggunaan paling umum dari COD adalah dalam mengukur jumlah polutan teroksidasi yang ditemukan dalam air permukaan (misalnya danau dan sungai) atau air limbah ${ }^{(3)}$. Dalam berbagai literatur sebelumnya, lindi dari suatu TPA yang berusia muda akan memiliki konsentrasi organik (sebagai COD) di atas $10.000 \mathrm{mg} / \mathrm{l}$, sedangkan pada TPA yang usianya di atas 10 tahun biasanya COD di bawah $3.000 \mathrm{mg} / \mathrm{(}^{(15,16)}$.Nilai COD juga dipengaruhi oleh tingkat ketersediaan oksigen. Dalam kondisi anaerob (tanpa oksigen) seperti halnya dalam lisimeter ini, kemungkina akan lebih tinggi dibanding dalam kondisi aerob. Hasil pengukuran COD pada penelitian ini mendapatkan angka minimal $6.300 \mathrm{mg} / \mathrm{l}$ dan maksimal $12.200 \mathrm{mg} / \mathrm{l}$ dengan nilai rata-rata 9.679,7 mg/l.Fluktuasi nilai COD selama penelitian di tunjukkan dalam Gambar 2. Tingginya angka COD menunjukkan usia sampah yang masih muda dan seiring periode pengamatan didapati penurunan nilai COD. Hasil pengamatan COD dalam studi menunjukkan bahwa sampel sampah dalam fase methanogenik. Dalam peraturan baku mutu lindi, nilai COD maksimal yang diperbolehkan adalah $300 \mathrm{mg} / \mathrm{l}$.

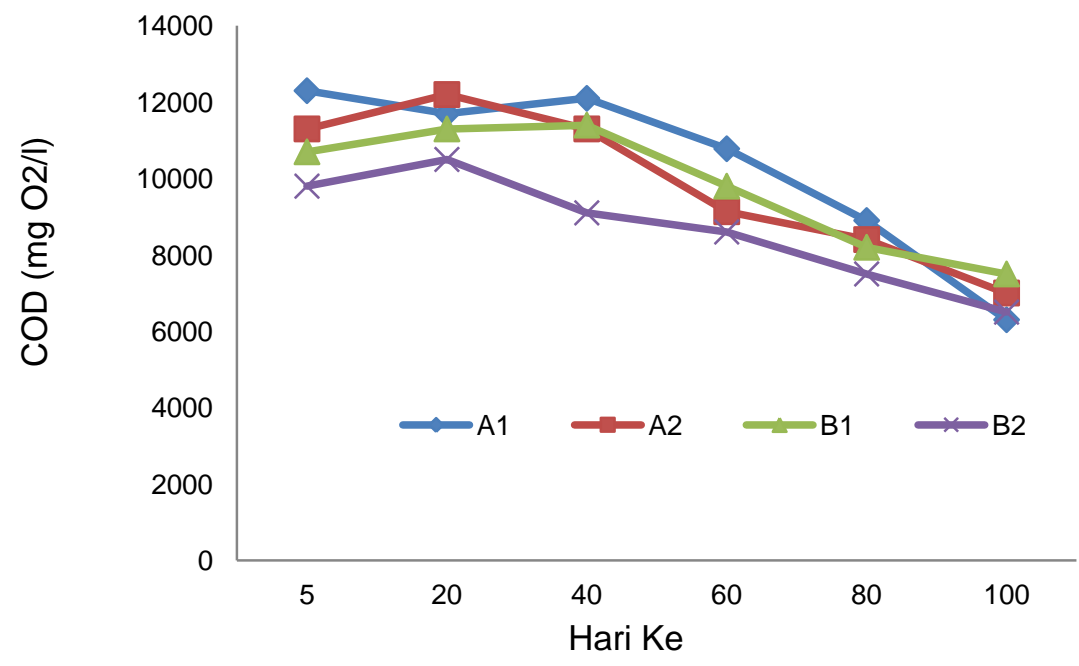

Gambar 3. Nilai COD lindi selama pengamatan

Kandungan material organik dalam lindi direpresentasikan dalam nilai $\mathrm{BOD}_{5}$ dan $\mathrm{COD}$. Sebagai tambahan rasio $\mathrm{BOD}_{5} / \mathrm{COD}$ juga penting dalam menilai jenis degradasi anaerobiksehingga angka ini penting dalam menentukan jenis pengolahan limbah cairnya ${ }^{(17)}$. Pada TPA di tahun-tahun awal pengoperasian, nilai rasio $\mathrm{BOD}_{5} / \mathrm{COD}$ berkisar 0,4 dan 0,8 memperlihatkan kondisi yang bagus bagi biodegradability kandungan organik dengan pengolahan anaerobik $^{(6,18)}$.Seperti umum diketahui bahwa organik dalam lindi memiliki aneka biodegradability. Dengan demikian, ukuran biodegradabilityserta efektivitas metode penyisihan polutan organiknya digunakanrasio $\mathrm{BOD}_{5} / \mathrm{COD}^{(18)}$. Dari sampel lindi yang diamati pada penelitian ini didapatkan angka rasio $\mathrm{BOD}_{5} / \mathrm{COD}$ sebesar 0,01 , yang berarti secara teoritis lindi masih bisa diolah secara aerob. Rendahnya nilai rasio $\mathrm{BOD}_{5} / \mathrm{COD}$ indikasi bahwa lindi berasal dari sampah yang belum matang (mature). Namun demikian angka ini belum mencerminkan kondisi polutan organik sepenuhnya dari sampah TPA Kaliwlingi karena singkatnya waktu pengamatan.

\section{4. $\mathrm{NH}_{3}-\mathrm{N}$}

Salah satu polutan organik yang umum di limbah cair adalah Nitrogen. Bentuk Nitrogen di limbah cair dapat berupa total Nitrogen ( $\mathrm{t}-\mathrm{N})$, Total Kjeldahl Nitrogen (TKN), Ammonia $\left(\mathrm{NH}_{4}\right)$, Organik Nitrogen $\left(\mathrm{NH}_{3}-\mathrm{N}\right)$, Nitrat $\left(\mathrm{NO}_{3}\right)$ dan Nitrit 
$\left(\mathrm{NO}_{2}\right)^{(19)}$.Salah satu parameter kandungan Nitrogen dalam lindi pada penelitian ini adalah Ammonia $\left(\mathrm{NH}_{3}-\mathrm{N}\right)$. Bila suatu limbah cair memiliki $\mathrm{pH}$ di bawah 7 umumnya akan banyak direpresentasikan kehadiran Ammonium $\left(\mathrm{NH}_{4}\right)$, sedangkan bila $\mathrm{pH}$ bergerak ke arah angka 8 maka akan didapati lebih banyak bentuk Ammonia $\left(\mathrm{NH}_{3}\right)^{(20)}$.

Dalam penelitian ini diperoleh nilai parameter $\mathrm{NH}_{3}-\mathrm{N}$ minimal $80 \mathrm{mg} / \mathrm{l}$ (sampel B1) serta maksimal $190 \mathrm{mg} / \mathrm{l}$ (sampel A1), atau nilai ratarata $141,7 \mathrm{mg} / \mathrm{l}$. Variasi nilai $\mathrm{NH}_{3}-\mathrm{N}$ selama periode penelitian dapat dilihat pada Gambar 3. Rendahnya angka $\mathrm{NH}_{3}-\mathrm{N}$ adalah karena masih singkatnya usia sampah dalam lisimeter. De (2016) dalam penelitiannya dengan TPA tertutup mendapatkan angka $\mathrm{NH}_{3}-\mathrm{N}$ sebesar 1.681,67 $\mathrm{mg} / \mathrm{l}$ pada $\mathrm{pH}$ sekitar $8,3^{(13)}$. Secara umum dari berbagai literatur menunjukkan bahwa nilai $\mathrm{NH}_{3}$ $\mathrm{N}$ pada lindi yang diambil dari TPA akan lebih tinggi bila dibanding dengan yang berasal dari lisimeter ${ }^{(21)}$. Hal ini dapat dipahami mengigat lindi dari TPA lebih beragam dalam jumlah dan jenis sampahnya. Sebaliknya lindi dari hasil lisimeter belum tentu semua sampahnya mengandung atau melepaskan unsure nitrogen.

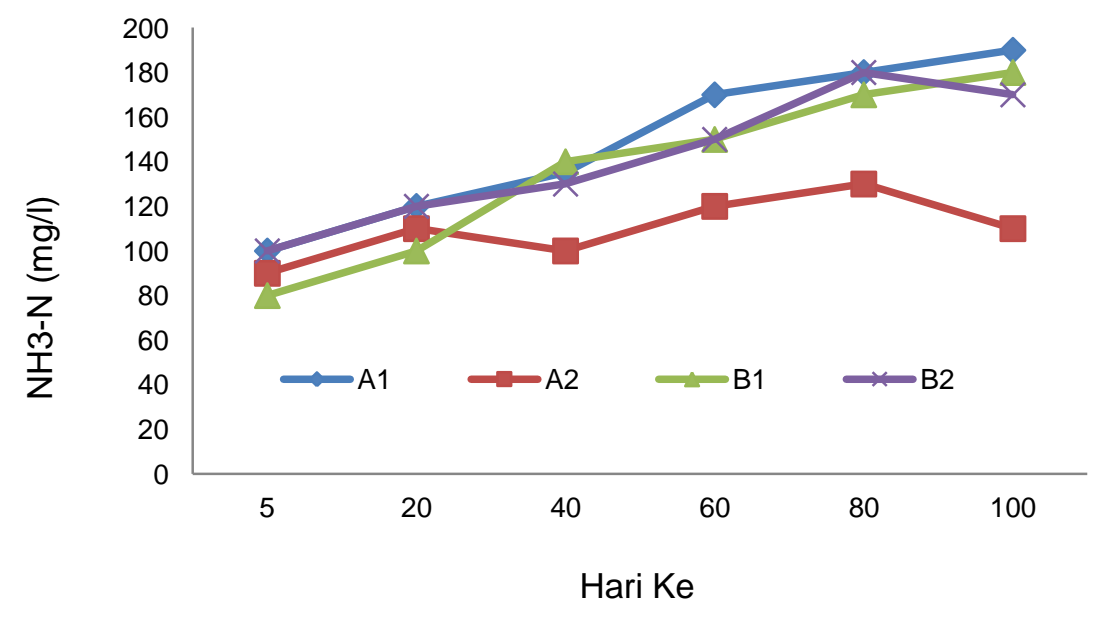

Gambar 4. Nilai $\mathrm{NH}_{3}-\mathrm{N}$ lindi selama pengamatan

\subsection{Total Kejeldah/ Nitrogen}

Total Kejeldahl Nitrogen (TKN) adalah parameter yang ditetapkan U.S EPA untuk mengukur kandungan organik Nitrogen (org-N, dalam hal ini $\mathrm{NH}_{3}-\mathrm{N}$ ) dan Ammonia $\left(\mathrm{NH}_{4}\right)$. TKN termasuk salah satu parameter yang harus diukur untuk monitoring instalasi pengolahan limbah cair saat ini. Berdasar penelitian yang telah ada, untuk TPA usia muda nilai TKN berkisar $100 \mathrm{mg} / \mathrm{l}$ sementara jika TPA sudah stabil maka bisa diperoleh TKN sekitar 2.000 $\mathrm{mg} / \mathrm{I}^{(22)}$. Dalam penelitian ini nilai TKN lindi minimal $540 \mathrm{mg} / \mathrm{l}$ (sampel A1) dan maksimal 890 $\mathrm{mg} / \mathrm{l}$ (sampel B1), dengan nilai rata-rata sebesar $672,54 \mathrm{mg} / \mathrm{l}$ (lihat Gambar 4). Mengingat konsentrasi awal TKN sulit diperkirakan serta diduga akan lebih besar dari $5 \mathrm{mg} / \mathrm{l}$, maka penentuan TKN dengan metode titrasi. Nilai ratarata TKN sebesar $672,54 \mathrm{mg} / \mathrm{l}$ yang lebih besar dari nilai $\mathrm{NH}_{3}-\mathrm{N}$ yang sebesar $141,7 \mathrm{mg} / \mathrm{l}$ sudah sesuai teori dan diperkirakan selisih keduanya adalah kandungan Ammonia $\left(\mathrm{NH}_{4}\right)$ dalam lindi.

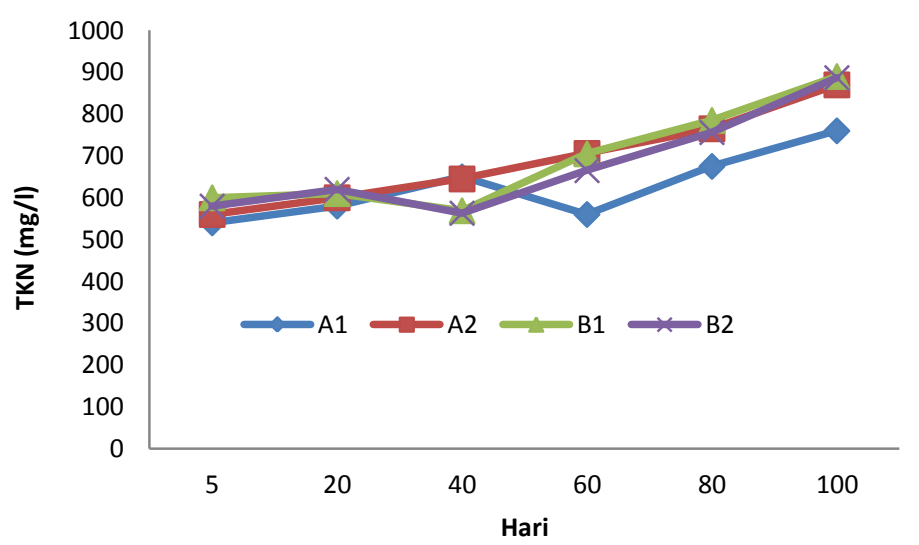

Gambar 5. Nilai total kejeldah/ nitrogen lindi selama pengamatan 
Hasil karakterisasi lindi secara umum menunjukkan bahwa kualitas lindi mencerminkan jika sampah yang diteliti masih terus melangsungkan proses dekomposisi atau masih usia muda. Pengamatan lindi dalam lisimeter idealnya selama minimal satu tahun. Rasio $\mathrm{BOD}_{5} / \mathrm{COD}$ yang 0,01 konsisten dengan nilai TKN yang masih tergolong tinggi menunjukkan proses dekomposisi organik yang terus berlangsung. Semakin lama usia TPA atau semakin stabil suatu TPA akan meningkat pula rasio $\mathrm{BOD}_{5} / \mathrm{COD}$. Nilai rasio $\mathrm{BOD}_{5} / \mathrm{COD}$ yang rendah mengindikasikan sulitnya pengolahan yang harus dilakukan untuk menurunkan kandungan materi organik dalam lindi dibanding lindi pada TPA-TPA yang sudah stabil atau usia tua. Adapun nilai $\mathrm{NH}_{3}-\mathrm{N}$ yang masih tergolong rendah menunjukkan bahwa dalam proses biodegradasi, kandungan protein dalam sampah belum sepenuhnya terlarut dalam lindi.

Dalam peraturan baku mutu lindi, kandungan Nitrogen diukur sebagai $\mathrm{N}$-total yang merupakan jumlah TKN, $\mathrm{NO}_{3}$ dan $\mathrm{NO}_{2}$. Total-N maksimal yang diijinkan adalah $60 \mathrm{mg} / \mathrm{l}$. Pengolahan secara biologi untuk nitrogen umumnya dilakukan dengan nitifikasi dan denitrifikasi. Tabel 2 menunjukkan hasil karakterisasi lindi secara keseluruhan.

Tabel 2. Kualitas lindi TPA Kaliwlingi, Brebes

\begin{tabular}{cccccc}
\hline $\begin{array}{c}\text { Parameter } \\
\left(\mathrm{mg} / \mathrm{l}^{*}\right)\end{array}$ & $\mathrm{A} 1$ & $\mathrm{~A} 2$ & $\mathrm{~B} 1$ & $\mathrm{~B} 2$ & Rerata \\
\hline $\mathrm{pH}$ & 7,5 & 7,6 & 7,8 & 7,6 & 7,6 \\
$\mathrm{BOD}_{5}$ & 99,5 & 82,8 & 99,2 & 81,2 & 90,7 \\
$\mathrm{COD}$ & 10347 & 9888 & 9817 & 8667 & 9679,7 \\
$\mathrm{BOD}_{5} / \mathrm{COD}$ & 0,01 & 0,01 & 0,01 & 0,01 & 0,01 \\
$\mathrm{NH}_{3}-\mathrm{N}$ & 149,2 & 110 & 136,7 & 141,7 & 134,4 \\
$\mathrm{TKN}$ & 627,5 & 691 & 693,2 & 678,5 & 672,5 \\
\hline kecuali $\mathrm{pH}$ & & & & &
\end{tabular}

\section{KESIMPULAN}

1. Melalui percobaan lisimeter dalam penelitian ini, kuantitas lindi per massa sampah ratarata mencapai 1.060 liter $/ \mathrm{kg}$, semakin tinggi kadar airmenunjukkan semakin besar kuantitas lindi yang dihasilkan serta nilai $\mathrm{pH}$ lindi rata-rata 7,6 cenderung alkaline.

2. Karakterisasi lindi didapatkan nilai rata-rata serta rentang minimal-maksimal sebagai berikut; $\mathrm{BOD}_{5} 90,7 \mathrm{mg} / \mathrm{l}(65 \mathrm{mg} / \mathrm{l}-130 \mathrm{mg} / \mathrm{l})$, COD $9.679,7 \mathrm{mg} / \mathrm{l}(6.300 \mathrm{mg} / \mathrm{l}-12.200 \mathrm{mg} / \mathrm{l})$, $\mathrm{NH}_{3}-\mathrm{N} 134,4 \mathrm{mg} / \mathrm{l}(80 \mathrm{mg} / \mathrm{l}-190 \mathrm{mg} / \mathrm{l})$ dan TKN 672,5 mg/l (540 mg//-890 mg/l). Secara umum dapat disimpulkan bahwa polutan utama dalam lindi adalah materi organik dan nitrogen-ammonia.

3. Rasio $\mathrm{BOD}_{5} / \mathrm{COD}$ sebesar 0,01 menunjukkan tingkat low biodegradability dalam materi organiknya, hal ini disebabkan waktu pengamatan yang relatif singkat dan proses dekomposisi biologis masih berlangsung, sehingga belum menunjukkan karakter rasio $\mathrm{BOD}_{5} / \mathrm{COD}$ yang representatif untuk sampah di TPA. Hasil yang diperoleh dalam studi ini masih mengindikasikan bahwa lindi yang ada masih sulit untuk diolah agar sesuai baku mutu.

4. Perlu dilakukan penelitian karakteristik lindi dalam periode yang lebih lama setidaknya setahun untuk mendapatkan data lindi yang dapat digunakan dalam menentukan metode pengolahannya di TPA.

\section{PERSANTUNAN}

Ucapan terima kasih kami sampaikan kepada tim Dinas Pekerjaan Umum dan Tata Ruang dan Kantor LH Kabupaten Brebes yang telah mendukung pelaksanaan observasi lapangan serta tim mahasiswa Teknik Lingkungan Universitas Winayamukti yang telah mendukung kerja laboratorium hingga terlaksananya penelitian ini.

\section{DAFTAR PUSTAKA}

1. Purwanta, W., R. W. Soemantojo, S. Widanarko, dan S. Bismo, (2012), Uji eliminasi gas metana $\left(\mathrm{CH}_{4}\right)$ dengan biofiltrasi pada unggunkompos dan tanah penutup landfill,J. Tek. Ling., Edisi Khusus Hari Lingkungan Hidup : 1-10

2. Damanhuri, E., T. Padmi, (2016), Pengelolaan Sampah Terpadu. Penerbit ITB, Bandung.

3. Tchobanoglous, G., F.Kreith (2002). Handbook of Solid Waste Management, $2^{\text {nd }}$ Edition, MacGraw-Hill.

4. Dinas Pekerjaan Umum \& Tata Ruang Kabupaten Brebes, (2012), Rencana Pengembangan TPA Kaliwlingi, Dokumen Teknis.

5. Hartono, E., (2006), Peningkatan pelayanan pengelolaan sampah di Kota Brebes melalui peningkatan kemampuan pembiayaan, 
Thesis Magister, Universitas Diponegoro, Semarang.

6. Ehrig, H.J., (1983), Quality and quantity of sanitary landfill leachate, Waste Management \& Research, I, 53-68.

7. Kulikowska, D., E. Klimiuk, (2008), The effect of landfill age on municipal leachate composition, Bioresource Technology, 99 :5981-5985.

8. Paxe'us, N., (2000), Organic compounds in municipal landfill leachates, Water Sci. Technol., 42 : 323-333.

9. Kurniawan, T.A., W.H.Lo, , G.W. Chan, (2006), Degradation of recalcitrant compounds from stabilized landfill leachate using a combination of ozone-GAC adsorption treatment,J. Hazard. Mater, B137 : 433-455.

10. Aziz, S. Q. , H. A. Aziz , M.S. Yusoff, M. J.K Bashir, M. Umar, (2010), Leachate characterization in semi-aerobic and anaerobic sanitary landfills: A comparative study, Journal of Environmental Management, $91: 2608-2614$.

11. Baucom, I.K, C.H. Ruhl, (2013),CCP Landfill leachate generation and leachate management, 2013 World of Coal Ash (WOCA) Conference-April 22-25, 2013 in Lexington, $\mathrm{KY}$.

12. Al-Wabel, M.I.,W.S. Al Yehya, A.S. ALFarraj, S.E. El-Maghraby, (2011), Characteristics of landfill leachates and biosolids of municipal solid waste (MSW) in Riyadh City,Saudi Arabia,Journal of the Saudi Society of Agricultural Sciences, 10 (2) :65-70.

13. De,S., S.K. Maiti, T. Hazra, A. Debsarkar, A. Dutta, (2016), Leachate characterization and identification of dominant pollutants using leachate pollution index for an uncontrolled landfill site,Global J. Environ. Sci. Manage., 2(2): 177-186.

14. Chian, E.W.K.,and F. B. DeWelle, (1977), Evaluation of leachate treatment, Volume 1, Characterization of Leachate, EPA-600/2-77186a, U.S Environmental Protection Agency, Cincinnati, Ohio, USA

15. Chang, J.-E., (1989), Treatment of landfill leachate with an upflow anaerobic reactor combining a sludge bed and a filter, Water Sci. Technol., 21 : 133-143.

16. Chen, P.H., (1996), Assessment of leachates from sanitary landfills: impact of age, rainfall and treatment, Environ. Int., 22 : 225-237.

17. Putri, A. R., G. Samudro, D.S. Handayani, (2013), Penentuan rasio BOD/COD optimal pada reaktor aerob, fakultatif dan anaerob,Jurnal Teknik Lingkungan, 2 (1) : 15.

18. Marttinen, S.K., R.H.Kettunen, J.A.Rintala, (2003), Occurrence and removal of organic pollutants in sewages and landfill leachates,Sci. Total Environ. 301 : 1-12.

19. Qifei, H., Y. Yufei, P. Xiangrui, W. Qi, (2008), Evolution on qualities of leachate and landfill gas in the semi-aerobic landfill,Journal of Environmental Sciences, 20 : 499-504

20. Karnchanawong, S., P. Yongpisalpop, (2009), Leachate generation from landfill lysimeter using different types of cover soil,Int. J. of Civil and Env. Eng., 1 (3): 126130

21. Timothy, G., (1998), Characteristic of leachate from construction and demolition waste landfills, Department of Environmental Science University of Florida, Gainesville

22. Qdais, A., A.A. Alsheiradeh, (2008), Kinetics of solid waste biodegradation in laboratory lysimeters, Jordan Journal of Civil Engineering, 2(1): 20-25. 